\title{
Argumentos para uma Dissociação da Filosofia Política de Thomas Hobbes da Tradiç̧ão Realista*
}

\author{
lara Costa Leite**
}

\author{
"The great political philosophers demand being read and \\ read again, and one finds that each rereading brings an \\ enlarged and deepened understanding." \\ Kenneth Waltz, Man, the State and War, 1959.
}

Quando se fala em anarquia internacional, a primeira imagem que nos vem à cabeça é, certamente, aquela que diz respeito à ausência de uma entidade central, nos moldes de um governo nacional, que comande a ação dos Estados de forma eficaz. Embora essa imagem seja consensual entre os estudiosos das relações internacionais, suas implicações variam consideravelmente, e dependem das motivações atribuídas às unidades e da caracterização dos processos e do sistema em que tais unidades se encontram inseridas. Assim, de maneira

* Artigo recebido em agosto e aceito para publicação em outubro de 2004.

** Iara Costa Leite é mestre pelo Instituto de Relações Internacionais da Pontifícia Universidade Católica do Rio de Janeiro (IRI/PUC-Rio) e pesquisadora do Observatório Político Sul-Americano (OPSA/IUPERJ). 
simplificada, pode-se dizer que, para os realistas, a anarquia internacional terá como resultado o conflito; para os institucionalistas, a cooperação; e para os construtivistas, o conflito ou a cooperação, dependendo dos processos de socialização (ou cultura) que pautam a conduta das unidades.

Para validar suas teorias, bem como a realidade que buscam descrever/explicar, os autores de cada uma dessas "escolas" - notadamente os realistas - fazem referência a textos clássicos, muitas vezes seguindo uma tradição analítica que, partindo de critérios e preocupações presentes, seleciona e reúne algumas idéias de grandes filósofos do passado. Os autores acima referidos tomam como funcionalmente similares essas idéias, reunindo-as em torno de uma epopéia dotada de fortes qualidades apelativas por apresentar-se como história real da disciplina. Isso não poderia ser mais conspícuo do que no tema central que vem pautando historicamente os debates disciplinares das relações internacionais: o discurso político da anarquia (Schmidt, 1998).

Apesar das inúmeras contestações acerca do conceito e das implicações da condição anárquica, a prevalência de um discurso positivista, para o qual a veracidade das asserções repousa no objeto externo (Ashley, 1986), acabou por dar proeminência a uma interpretação naturalista da anarquia, interpretação que se fortalece pela omissão de controvérsias históricas que demonstrariam ser a anarquia não um fato empírico auto-referenciado, mas função de um debate disciplinar (Schmidt, 1998). A tentativa de emular as ciências naturais, em busca de leis gerais, levou também a uma tendência a-historicista, fortemente afirmada pelo neo-realismo, de se tratar a anarquia como elemento perene da política internacional, quando inúmeros estudos históricos demonstram o contrário. Barry Buzan e Richard Little (2000:21) chamam essa tendência de "anarchophilia".

Silenciados também são o contexto em que se encontravam inseridos os autores dos "grandes textos", bem como interpretações que não 


\section{Argumentos para uma Dissociação da}

Filosofia Política de Thomas Hobbes...

servem aos propósitos de legitimação dos princípios realistas; as “teorias políticas" de Tucídides, Maquiavel, Hobbes e Rousseau, por exemplo, são tidas como reveladoras ilustres de premissas que viriam a formar o "núcleo duro" de um programa de pesquisa ${ }^{1}$. Muitas vezes, a obra de cada um desses filósofos é reduzida a poucas frases, ou a uma apenas, e o apelo a elas torna-se ferramenta na reificação da estrutura anárquica, principalmente quando já se encontram canonizadas em torno de um senso comum (Campbell, 1992; Walker, 1993). Um exemplo ilustrativo, pois mostra até que ponto a simplificação dos grandes textos pode chegar, é a constatação de Gilpin (1984:290) de que: "Como Thomas Hobbes disse a seu patrono, o segundo conde de Devonshire, e escritores realistas sempre tentaram dizer àqueles que escutassem, 'é uma floresta lá fora'. A anarquia é a regra; a ordem, a justiça e a moralidade são exceções”.

Até mesmo os críticos da abordagem realista parecem concordar com o "realismo" da imagem hobbesiana das relações internacionais, embora a repudiem de várias formas, inclusive introduzindo outros filósofos políticos (como Kant, Grotius, Locke e Montesquieu) que legitimem suas críticas e dêem espaço para a emergência de novas abordagens. Keohane, por exemplo, afirma que

"Estados são entidades independentes com interesses diversos e não têm garantias de que outros Estados agirão benignamente com relação a eles ou mesmo manterão seus compromissos. Como Kenneth N. Waltz expressou, a política mundial é um sistema de auto-ajuda no qual os Estados buscam manter seu poder e, na medida do possível, expandi-lo, e no qual estão preocupados com seu poder em relação aos outros, bem como com o bem-estar próprio. Uma das primeiras e mais poderosa expressão desses pressupostos sobre a natureza e interações humanas foi enunciada por Thomas Hobbes no século dezessete" (1995:166-167, ênfases minhas).

Um dos componentes fulcrais do discurso da anarquia é a referência às relações internacionais como análogas ao estado de natureza (Schmidt, 1998:90). Muitos dos debates ocorridos na disciplina de relações internacionais, desde sua "pré-história", foram delimitados 
por esse tema, seja ele aceito, qualificado ou repudiado. O que se pode notar, em geral, é que os questionamentos da noção realista da anarquia internacional são feitos de três maneiras: pela introdução de fatores históricos que demonstram que os pressupostos da analogia (igualdade, independência, Estados como únicos atores soberanos, inexistência de leis internacionais) não se sustentam; por uma discussão teórica sobre os fundamentos sociais, e não estatais, da lei; e por uma modificação das motivações atribuídas aos Estados, bem como dos processos em que se encontram inseridos. Neste último caso, tem-se que a anarquia internacional: pode gerar padrões cooperativos em torno de instituições internacionais caso as unidades sejam movidas pela maximização da utilidade - Keohane -; é ela mesma produto de uma cultura compartilhada que se encontra suscetível à mudança - Wendt -; é uma forma de governo porque distribui benefícios - Onuf.

O problema é que inexistem disputas quanto à suposta origem filosófica da analogia entre estado de natureza e relações internacionais, qual seja, o pensamento de Thomas Hobbes. Assim, não se questiona a unidade conceitual dos autores que vieram a compor o épico realista, mas apenas sua correspondência com a "história real" das relações internacionais. A questão é que a própria seleção dos fatos é determinada pelos modelos teóricos de cada escola, modelos esses que, por sua vez, legitimam-se tanto pela "cientificidade" de sua elaboração quanto pela referência a grandes filósofos do passado que teriam supostamente revelado leis semelhantes. Mais do que isso, parece existir um reconhecimento acadêmico tácito de que, se uma escola já consagrou um filósofo como "um dos seus", sua obra torna-se automaticamente inútil às "escolas rivais", e seu estudo é tido como desnecessário.

Nesse contexto, a proposta deste artigo é revisitar a obra de um dos heróis da "tradição realista", Thomas Hobbes, de forma a desconstruir a axiomática noção das relações internacionais como estado de 


\section{Argumentos para uma Dissociação da}

Filosofia Política de Thomas Hobbes...

natureza. Os argumentos aqui apresentados se inserem em esforços mais amplos, oriundos notadamente de diversos estudos das ciências sociais e da história, cujo propósito é o de, com base em análises mais detalhadas do contexto intelectual e histórico vivenciado pelo filósofo em questão, mostrar que muitos dos termos comumente associados a seu nome - como o caráter a-histórico de suas análises, seu materialismo, sua unidade metodológica, sua psicologia egoísta, sua defesa de um governo arbitrário e até mesmo sua convicção de ter descoberto as verdadeiras bases de uma filosofia moral - são, no mínimo, problemáticos ${ }^{2}$. Isso não significa, porém, que esses recentes mergulhos nos textos de Hobbes façam emergir uma essência de seu pensamento. Pelo contrário, a conclusão alcançada por grande parte dos estudiosos engajados no estudo da obra do filósofo diz respeito justamente à impossibilidade de tornarmos perfeito e completo seu entendimento ${ }^{3}$.

Apesar disso, situar a obra de Hobbes em seu tempo não deixa de ser um esforço necessário caso se queira afastar, mesmo que minimamente, de novas reificações com propósitos pautados por disputas acadêmicas. No que se refere ao contexto histórico-intelectual de sua filosofia civil, vale lembrar que o Leviatâ $\tilde{a}^{4}$ foi escrito em meio à guerra civil inglesa e que o que o torna distinto dos trabalhos anteriores é basicamente o ceticismo do filósofo quanto à capacidade de os indivíduos, movidos pelos seus interesses particulares, internalizarem as verdades descobertas pela razão (Skinner, 1999). Ao ponderar sobre as causas do conflito, a pergunta de Hobbes é por que, tendo ele já descoberto e difundido as verdadeiras bases da ciência civil, as pessoas não a teriam levado em conta (uma vez que, se o tivessem, não teria havido guerra civil). E a resposta encontrada foi: porque seus concidadãos eram educados pelos eclesiásticos (que pregavam a falsa doutrina da desobediência) e porque, mediante a eloqüência de seu enunciado, triunfavam idéias perniciosas difundidas pelos democratas da Câmara dos Comuns. 
Assim, a decisão de Hobbes foi retomar, em seu Leviatã, o ideal renascentista que antes havia repudiado - qual seja, o de que a razão teria pouco poder de convencimento, e deveria ser suplementada pelas artes da retórica. O propósito do texto em questão continuava a ser, assim como o dos anteriores, garantir a ordem doméstica e a obediência dos súditos pela demonstração de premissas tidas como intrínsecas à experiência. A premissa maior teria sido herdada do único princípio universal que se manteve intacto ao ataque cético às verdades atreladas ao comportamento humano: a autopreservação (Tuck, 2001). Hobbes, porém, ao observar o comportamento orgulhoso dos indivíduos, acabou por repudiar esse núcleo mínimo como descritivo da natureza humana, convertendo-o em base normativa para a demonstração de uma ética verdadeira.

Duas conclusões, que podem ser tiradas com base na exposição acima, afetam diretamente o modo como são tratadas as idéias do filósofo pelos estudantes de relações internacionais. Em primeiro lugar, em toda a obra de Hobbes, fica patente que as questões relacionadas à paz e à guerra entre as nações não constituem tema central. Uma explicação razoável poderia ser a de que, tendo em vista o caráter mais sangrento das guerras civis, seria necessário que a ciência política se voltasse para a descoberta dos princípios necessários à paz interna. Acreditamos, porém, que dificilmente se poderia conceber a contraposição do domínio doméstico ao internacional, uma vez que a base dessa distinção, isto é, uma autoridade central plenamente constituída, não existia na época de Hobbes (se é que existiu algum dia). Em última instância, embora seja comum que se atribua ao filósofo a introdução de uma distinção entre as dimensões interna e externa da autoridade política (ver, por exemplo, Hutchings, 1999:18), “[...] não é de todo certo que Hobbes ou quaisquer de seus contemporâneos tenham conceitualizado as relações internacionais como um 'domínio', ou como um conjunto distintivo de relações que poderiam ser sujeitas a comparações com outro domínio" (Onuf e Onuf, no prelo). 


\section{Argumentos para uma Dissociação da}

Filosofia Política de Thomas Hobbes...

Mostrar o caráter inextricável entre interno e externo, na obra de Hobbes, significa não apenas extrair de sua filosofia civil possibilidades extensivas à ordem mundial, mas principalmente chamar a atenção para o fato de que o "estado de guerra internacional" estava intimamente associado às instabilidades domésticas. O problema é que a teoria realista, imersa na reificação da efetividade do Estado moderno, encara as relações internacionais como domínio separado e oposto à ordem doméstica, naturalizando assim a fundamentação do dualismo interno-externo na dicotomia estado de natureza-estado civil.

Em segundo lugar, a história épica realista, ao resgatar os pensamentos de Maquiavel e Hobbes, tratando-os como aqueles que capturaram as verdades eternas da política, deixa de considerar precisamente o dilema em que se encontravam tais pensadores, por terem vivido em um momento caracterizado pelo colapso de valores universalistas e pelo caráter altamente contestável da humanidade como categoria política (Walker, 1993:16). No caso de Hobbes, embora tenha considerado a si próprio como revelador da verdadeira ciência civil ${ }^{5}$, não considera seus princípios primeiros, fundamentados na redução das motivações humanas ao medo da morte violenta, como tendo apreendido todos os comportamentos que observava à sua volta. Muitos homens não se preocupavam com sua sobrevivência, mas principalmente com o reconhecimento de suas virtudes pelos seus pares reconhecimento este que, não sendo alcançado, poderia levar a toda espécie de atos insanos, inclusive à guerra civil.

Quer dizer, o próprio Hobbes constatou o caráter problemático do tratamento das motivações humanas segundo lentes reducionistas e universalistas, o que torna no mínimo diletante a posterior análise das relações internacionais a partir de um modelo de estado de natureza cujos pressupostos e implicações já haviam sido reconhecidos pelo seu autor como insuficientes para descrever a desordem real embora suficientemente apelativos para transformá-la. Apesar do 
cunho fortemente normativo da filosofia política de Hobbes, a teoria realista de relações internacionais - particularmente em sua versão estrutural - utiliza-se de diversas categorias (principalmente aquelas veiculadas por seu modelo de estado de natureza) para descrever a realidade inexorável da anarquia internacional.

Nesse sentido, são dois os objetivos específicos deste artigo. Em primeiro lugar, resgatar o caráter hipotético do reducionismo motivacional do modelo de estado de natureza hobbesiano, trazendo à luz a noção de ciência em que se fundamenta - o nominalismo - e suas dissociações com relação à descrição do comportamento dos homens avançada por Hobbes. Em segundo lugar, explorar o argumento, cujo pressuposto é que as relações internacionais não constituíam um domínio separado das esferas domésticas, de que a resolução do problema da ordem doméstica poderia ter implicações diretas para a resolução do problema da liberdade de todos os soberanos a tudo (tanto em suas relações mútuas como em suas relações com os súditos).

Pode-se perguntar o que garante, afinal, a plausibilidade desses argumentos, ou mesmo por que são preferíveis às interpretações realistas de Hobbes. E a resposta é que a discussão que se segue resulta de um estudo mais atento ao contexto histórico e intelectual no qual está inserida a obra de Hobbes, além de constituir uma tentativa de tornar mais dialógica a interpretação do internacional em uma disciplina que na maior parte dos casos dispensa a necessidade de se questionarem as concepções filosóficas em que se fundamenta. Esse propósito se encaixa perfeitamente, a meu ver, nos objetivos da desconstrução. Segundo Ashley (1988:252),

"O efeito da desconstrução é permitir a abertura de um discurso ao mostrar que as fundações que lhe atribuíam uma suposta identidade, que proviam sua evidente estabilidade de propósito, e que definiam a necessidade de seus limites aparentes nunca estiveram tão seguras quanto pareciam. Elas nunca teriam sido mais do que efeitos de práticas de representação que se fizeram 


\section{Argumentos para uma Dissociação da}

Filosofia Política de Thomas Hobbes...

valer apenas enquanto vozes rivais de uma cultura sempre incerta podiam ser excluídas ou silenciadas".

De antemão, gostaria de deixar claro que não tenho pretensões hermenêuticas no desenvolvimento deste artigo, pois concordo com a noção construtivista, baseada em Wittgenstein, de que conceitos como "estado de natureza" e "anarquia internacional" são dotados de significado para os estudantes de relações internacionais, “[...] não porque capturaram a essência ontológica das 'coisas' [...], mas porque foram usados de uma certa maneira entre falantes que por meio deles se comunicaram uns com os outros" (Kratochwil, 2001:20).

É claro que, se o pensamento de Hobbes não apresenta uma essência, e se é rico em contradições, fica difícil, pelo menos à primeira vista, repudiar sua interpretação realista em favor de outra. Meu objetivo, porém, não é tornar ilegítima a interpretação realista, mas torná-la ilegítima como interpretação única, que pretende descrever uma realidade inexorável à política internacional - a anarquia internacional como estado de natureza. Acredito (embora não deseje explorar essa questão) que o que permitiu a naturalização dessa analogia foi o fato de se ter tornado um ato discursivo que, pela sua constância repetitiva (e pelo também repetitivo silenciamento de outras interpretações), acabou por levar os interlocutores a associá-lo não a um sujeito, mas a uma realidade, e a agirem como se ela existisse. Daí o fato de se atribuir à analogia entre relações internacionais e estado de natureza um status de ontologicamente perigosa (Odysseos, 2002) ${ }^{6}$.

Tampouco tenho a pretensão, ao sistematizar algumas interpretações dissidentes da filosofia política de Hobbes, de difundir quaisquer enunciados dotados de imparcialidade. Mesmo a abordagem que tomei como pressuposto, o construtivismo, apresenta categorias historicamente formadas, que pouco servem como fundações teóricas (Kratochwil, 2001). Portanto, a tarefa principal de minha argumentação diz respeito ao objetivo abraçado pela teoria crítica: realizar uma análise, mesmo que ainda incipiente (dada a marginalidade com que 
Iara Costa Leite

vem sendo tratado o tema na disciplina de relações internacionais), dos elementos da filosofia política de Hobbes que constituem uma das bases centrais dos nossos entendimentos disciplinares.

\section{O Estado de Natureza Internacional Qualificado}

Os termos utilizados por Hobbes no capítulo XIII de seu Leviatã , cujo objetivo é descrever uma suposta condição natural dos homens, encontram ressonância em toda a cadeia descritiva/explanatória do comportamento das unidades na anarquia internacional: na ausência de uma estrutura hierárquica de poder, não há restrições formais à expansão dos Estados, e estes, como atores racionais unitários e funcionalmente iguais, direcionam todos os seus esforços à garantia de sua segurança. A manutenção da independência, seja com relação às outras unidades, seja com relação a instituições internacionais, é tida como essencial, pois não há um poder central capaz de obrigar o cumprimento das promessas, de garantir uma distribuição justa dos ganhos da cooperação e, em última instância, de impedir que estes sejam convertidos em diferenciais de poder militar. A única forma racional, segundo o realismo, de impedir que um possível ataque se concretize é acumular poder material, ou seja, os Estados devem direcionar todos os seus esforços para a segurança. O problema é que, em vez de atingir o propósito último dessa acumulação - a autopreservação -, os Estados acabam se envolvendo em um "dilema de segurança":

"Lutando para obter segurança contra tal ataque, eles são impelidos a adquirir mais e mais poder a fim de escapar do impacto do poder alheio. Isso, por sua vez, torna os outros mais inseguros e os compele a se preparar para o pior. Já que nenhum deles jamais pode se sentir inteiramente seguro em tal mundo de unidades rivais, segue-se uma luta pelo poder, e o círculo vicioso da segurança e da acumulação de poder é acionado" (Herz, 2001:260). 


\section{Argumentos para uma Dissociação da}

Filosofia Política de Thomas Hobbes...

Nesse contexto, as únicas formas de ordem viáveis são aquelas produzidas pela competição, como a formação de alianças e o equilíbrio de poder, em que os Estados se juntam para fazer frente a uma ameaça comum e se separam assim que tal objetivo é alcançado. Como não são tão suscetíveis à destruição quanto os indivíduos no estado de natureza, essas formas temporárias de cooperação são tidas como suficientes para garantir a autopreservação das unidades e impedir que a condição anárquica se torne caótica.

É importante ressaltar que a analogia entre anarquia internacional e estado de natureza difundida pela teoria realista das relações internacionais não é, apenas, produto de longas lucubrações ou deduções lógicas que tomam como ponto de partida somente o que Hobbes tem a dizer a respeito dos indivíduos naturais. Ao contrário, a analogia em questão foi ligeira, mas explicitamente anunciada pelo próprio filósofo, conforme demonstram as seguintes citações:

“[...] as repúblicas, se consideradas em si mesmas, estão no estado de natureza, isto é, de hostilidade recíproca. E, mesmo que elas se abstenham de lutar, isso não se deve chamar paz, mas antes um tempo para respirar, no qual um inimigo, observando o movimento do outro e como este se porta, avalia sua segurança não em função dos pactos, mas das forças e desígnios do adversário" (Hobbes, 2002:201).

"Tal como então faziam as pequenas famílias, assim também fazem hoje as cidades e os reinos, que não são mais do que famílias maiores, para sua própria segurança ampliando seus domínios e, sob qualquer pretexto de perigo, de medo de invasão ou assistência que pode ser prestada aos invasores, legitimamente procuram o mais possível subjugar ou enfraquecer seus vizinhos, por meio da força ostensiva e de artifícios secretos, por falta de qualquer segurança; e em épocas futuras por tal são recordados com honra" (Hobbes, 1996:118).

"Filósofo: Que esperança há então de paz permanente em qualquer nação, ou entre uma nação e outra?

Jurista: Você não deve esperar uma paz dessa espécie entre duas nações, porque não existe poder universal neste mundo capaz de punir seus atos de injustiça: o medo mútuo pode mantê-las pacíficas por um tempo, mas diante 
Iara Costa Leite

de qualquer vantagem visível elas invadirão umas às outras [...]" (Hobbes, 1997:57).

Quer dizer, Hobbes admite, de maneira que não poderia ser mais evidente, que as relações entre Estados, analogamente à relação entre os indivíduos no estado de natureza, dizem respeito a um estado de guerra. Porém, como veremos logo adiante, passagens como as supracitadas não esgotam outras possibilidades de entendimento das relações internacionais que superem a linha divisória erigida pela disciplina entre o capítulo XIII do Leviatã e outros elementos da filosofia política hobbesiana (como a definição de ciência em que se baseia e o contexto em que foi elaborada).

É inegável que para a exclusão desses outros elementos contribuíram não apenas as interpretações realistas, mas também a interiorização de categorias taxonômicas que tomam como dada a incontestabilidade do status realista da obra de Hobbes ${ }^{7}$. Porém, essa associação da obra do filósofo com o realismo só se torna absoluta a olhares um tanto quanto desatentos, que tendem a concentrar-se em algumas passagens de uma obra vasta e rica (mesmo em contradições), sem as contraporem a outras e, o que talvez seja ainda mais grave, sem considerar as visões de mundo e de ciência que definem o pensamento de Hobbes, bem como seus propósitos ${ }^{8}$.

Quanto a estes, resumem-se a uma coisa apenas: a busca da paz (Hanson, 1984; Skinner, 1999; Bull, 2000). Se a preocupação central da obra de Hobbes é direcionar os caminhos para a paz, e se toma as nações como situadas em um estado de guerra umas com as outras, a seguinte questão emerge: por que o filósofo não menciona a necessidade de instituição de um governo mundial? Esta foi justamente a pergunta que norteou as pesquisas de alguns autores da Escola Inglesa em sua tentativa de ab-rogar a inclusão de Hobbes em uma tradição realista do pensamento internacional (Almeida, 1999). Veremos que isso foi feito por Bull de duas maneiras: (1) introduzindo uma série de restrições à analogia entre Estados e indivíduos e (2) trabalhando 


\section{Argumentos para uma Dissociação da}

Filosofia Política de Thomas Hobbes...

com a possibilidade de que as leis da natureza, como princípios universalizáveis (pois que divorciados de padrões morais ideológicos), constituíssem regras morais compartilhadas pelos Estados e tornassem mais moderadas suas ações 9 .

O problema é que Hobbes insiste no caráter imperfeito, apesar de genuíno, das leis da natureza (Navari, 1996), o que significa que elas têm caráter obrigatório, e que, em última instância, predomina, no estado de natureza incluindo-se a liberdade de todos a tudo, a interpretação do conteúdo das próprias leis da natureza. Ao mesmo tempo, porém, analisar as relações internacionais como se referindo a um estado de natureza se torna incongruente, dado o fato de que o último, dizendo respeito a um modelo hipotético cujo padrão interpretativo subjacente é o nominalismo hobbesiano, dificilmente pode ser convertido em constatações unívocas acerca do real. O primeiro argumento deste artigo buscará demonstrar, justamente, que o próprio Hobbes reconhece a limitação de seu modelo para descrever a realidade que o cerca. Assim, a transferência das motivações dos indivíduos naturais aos Estados, levada a cabo pelo realismo (especialmente em sua versão estrutural), torna-se um tanto quanto problemática.

Finalmente, a resposta para a pergunta já enunciada - por que Hobbes não cogita a feitura de um pacto entre os soberanos - terá como norte a hipótese de que grande parte das questões relacionadas à paz e à guerra entre as nações, tendo em vista o caráter inextricável entre o doméstico e o internacional no mundo seiscentista, não apenas remetia às relações entre soberanos dotados de motivações e propósitos específicos, mas estava especialmente condicionada à configuração da ordem social doméstica. Quer dizer, a resolução da liberdade com que se manifestavam as disputas internacionais - potencializadas que eram pelas instabilidades domésticas (mas também associadas à prontidão dos países vizinhos em invadir uns aos outros) - repousava, em última instância, não na instituição de um governo mundial, mas na resolução do problema da ordem doméstica. 


\section{Resgatando o caráter hipotético do estado de natureza}

Um problema fundamental que se revela na transposição dos pressupostos hobbesianos relacionados à motivação dos indivíduos - quais sejam, a racionalidade baseada no auto-interesse e a resignação ao poder material, sendo ambos fundamentados no medo da morte violenta - a uma abordagem realista é o fato de os teóricos que ela abrange se assumirem enquanto transmissores de noções que dizem respeito à realidade como ela é (Freyberg-Inan, 2004) ${ }^{10}$. A questão é que o modelo do estado de natureza apresentado por Hobbes se insere em uma definição de ciência bem distinta da realista, definição esta que é precedida pela crença de que as coisas às quais damos nomes são individuais e singulares, "[...] nada havendo no mundo universal além de nomes [...]" não há como extrair das coisas em si leis ou axiomas universalmente válidos; o verdadeiro e o falso, nesse sentido, são tidos como atributos das palavras, e não das coisas (idem: 27$)^{12}$. O propósito da ciência, então, não é conhecer as coisas em si (mesmo porque isso, na concepção de Hobbes, parece impossível), mas as conseqüências das palavras que utilizamos para defini-las - sendo o discurso científico, como qualquer outro, condicional, e não absoluto ${ }^{13}$ :

"Ninguém pode chegar a saber, por meio do discurso, que isto ou aquilo é, foi ou será, o que equivale a conhecer absolutamente. É possível apenas saber que, se isto é, aquilo também é; que, se isto foi, aquilo também foi; e que, se isto será, aquilo também será; o que equivale a conhecer condicionalmente. E não se trata de conhecer as consequiências de uma coisa para a outra, e sim as do nome de uma coisa para outro nome da mesma coisa" (idem:47).

A elaboração hobbesiana acerca do estado de natureza tem como fundamento esse modelo científico e se resume ao seguinte: se os homens buscam a sobrevivência, e se esta se encontra ameaçada no estado de natureza, os homens farão algo para sair dele (este algo é o contrato). Isso não significa, porém, que essa condição natural tenha 


\section{Argumentos para uma Dissociação da}

Filosofia Política de Thomas Hobbes...

existido de fato, ou mesmo que se possa, extraindo das motivações humanas um denominador comum mínimo e objetivo em torno do medo da morte, deixar de levar em conta os outros desejos que pautam a ação dos indivíduos.

No capítulo VI de seu Leviatã, Hobbes fala sobre uma miríade de paixões que motivam nossa ação: a esperança, o medo, a coragem, a indignação, a benevolência, a ambição, a vanglória, a luxúria, a gentileza etc. O problema é que o objeto dos desejos emocionais varia de pessoa para pessoa, e mesmo em uma única pessoa conforme o passar do tempo - daí a impossibilidade de se construir um modelo a partir das paixões. O objeto dos desejos racionais, porém, é uniforme, e diz respeito à autopreservação como um bem (Gert, 1996:164) ${ }^{14}$. O contrato só se realiza porque, em um determinado momento (também fictício), as mentes dos indivíduos acalmam-se, eles percebem que sua sobrevivência se encontra ameaçada e, em nome da prevalência do medo da morte sobre as outras paixões, buscam uma alternativa razoável ao estado de natureza: o governo civil.

Não obstante, desse raciocínio não se pode deduzir que a razão predomine, invariavelmente, sobre as paixões, o que fica claro, por exemplo, quando Hobbes afirma que "[...] qualquer sinal de ódio e desdém induz a maior parte dos homens a brigar e lutar, a tal ponto que a maioria deles preferiria perder a vida (e nem digo: a paz) a sofrer um insulto" (Hobbes, 2002:61) ${ }^{15}$. Quer dizer, embora seja natural o desejo racional de evitar a morte ${ }^{16}$, Hobbes reconhece que ele pode ser bem mais fraco que o desejo social de evitar a humilhação (Gert, 1996:165) ${ }^{17}$.

Deve-se fazer notar, contudo, que as paixões não são dotadas, por si próprias, de um caráter negativo; elas se tornam irracionais apenas quando colocam em risco a vida do indivíduo, o que ocorre quando são excessivas. À intensidade e veemência incomum das paixões, Hobbes atribui o significado da loucura, que resulta em fúria se pro- 
veniente do excesso de orgulho (como na passagem supracitada), e em medos infundados como aqueles observados em pessoas melancólicas (Hobbes, 1996:54; 1999:64). Ao contrário do medo justo, que baseado em uma antevisão de um mal futuro conduz, juntamente com uma série de outras virtudes sociais, à paz, o medo paranóico é normalmente um obstáculo à racionalidade tão significativo e conspícuo quanto a vanglória.

Ao afirmar que "[...] não é qualquer espécie de medo que justifica a ação que produz, mas apenas o medo de sofrimento corporal (a que se chama medo físico) [...]" (Hobbes, 1996:206, ênfases no original), Hobbes expressa, antes de tudo, uma questão normativa, um dever que, influenciando a conduta dos indivíduos, os levará a tomar como detentor do poder, e a obedecer, aquele que possui o direito de infligir castigos (embora não o devam obedecer, como veremos mais adiante, apenas por isso): o soberano. E a obediência ao soberano é racional - ou a sedição uma prática irracional - porque (e enquanto) é ele quem garante a sobrevivência dos súditos; daí a conclusão de que “[...] quem mover uma ação contra o soberano estará movendo-a contra si mesmo" (idem:153).

Em Behemoth, porém, Hobbes mostra-se consciente de que não era essa a realidade entre os ingleses de seu século (e entre os homens em geral), e de que a obediência ao rei (e, por conseguinte, a sobrevivência dos súditos) encontrava-se em ameaça constante - entre uma miríade de fatores que não me cabe aqui discutir - por causa da força com que se manifestavam tanto o medo da excomunhão (o que os tornava mais propensos a seguir os cânones papistas do que as leis civis) (Hobbes, 2001:39, 46) quanto as querelas intelectuais que infestavam as universidades e o parlamento e cujas partes insistiam veementemente na razão superior de suas opiniões ${ }^{18}$. O poder que os papas, escolásticos e membros da Câmara dos Comuns exerciam sobre a população baseava-se não na sua materialidade, mas meramente no fato de a população aceitar este poder enquanto tal. Ou seja, ao con- 


\section{Argumentos para uma Dissociação da}

Filosofia Política de Thomas Hobbes...

trário da concepção neo-realista de que somente o poder baseado em instrumentos de coerção compele a conduta das unidades em determinada direção, Hobbes deixa claro que "[...] o poder dos que o detêm não possui outro fundamento que a opinião e crença do povo" (idem:48).

Mencionei essas questões para chamar a atenção para o fato de que há mais nas motivações humanas, em Hobbes, do que nos faz crer a interpretação realista de sua filosofia política. Esta interpretação se baseia tão somente em um modelo hipotético cujas fundações seriam o auto-interesse e o medo (e aqui certamente os realistas se referem ao medo racional), e pode ser problematizada, como constata Kratochwil, na medida em que uma leitura mais atenta da obra do filósofo demonstra que tais fundações são influenciadas por fatores culturais. As paixões, Hobbes reconhece, podem muitas vezes ser contrárias à autopreservação, o que torna as ações que delas resultam irracionais. Ao refletir sobre o passado recente em sua época, a conclusão a que chega é de que "vistas como um todo, as ações das pessoas [...] são caracterizadas mais pela impulsividade e compulsões, frenesi e histeria, do que pela busca 'racional' do interesse [...]" (Kratochwil, 2001:25).

Nota-se, a partir das considerações acima realizadas, que Hobbes não constrói um discurso de exaltação da segurança (ou ausência de medo) do indivíduo no plano doméstico a partir da negação da esfera internacional (em que o medo se faz presente). Ao contrário, afirma, no Prefácio do Autor ao Leitor em Do Cidadão, que, tanto entre os países como entre os particulares, verifica-se um sentimento de medo mútuo:

"Vemos todos os países, embora estejam em paz com seus vizinhos, ainda assim guardarem suas fronteiras com homens armados, suas cidades com muros e portas, e manterem uma constante vigilância. [...] Vemos, até nos Estados bem governados, onde há leis e castigos previstos para os delinqüentes, que mesmo assim os particulares não viajam sem levar sua espada 
a seu lado, para se defenderem, nem dormem sem fecharem - não só suas portas, para proteção de seus cidadãos - mas até seus cofres e baús, por temor aos domésticos" (Hobbes, 2002:14, ênfases minhas).

Ainda no que se refere ao medo mútuo - e às atitudes defensivas que dele decorrem -, Hobbes diz que tem origem no fato de que, mesmo sendo os justos superiores aos injustos em número, não há como distingui-los. Nesse sentido, não devemos tomar o medo, a agressividade e o egoísmo como naturalmente definidores do caráter humano, mas como necessários em situações em que não há garantia de paz, o que não significa, porém, que o ser humano não deseje agir de outra forma ${ }^{19}$ - exercendo, por exemplo, a benevolência ${ }^{20}-$, mas apenas que não deve fazê-lo em situações em que há um medo justo com relação a outrem.

Essa explicação é incompatível com a fórmula de realismo clássico, normalmente atribuída a Hobbes, de que o medo é produto de uma natureza humana perversa ${ }^{21}$. Não há, segundo o filósofo, uma natureza humana má por si própria, e isso - levando-se em conta não seu modelo hipotético, mas o que tem a dizer a respeito da realidade cultural do homem - assim o é na medida em que a malícia só existe quando um homem, em idade madura e tendo adquirido força física que possa ser utilizada para causar danos a outrem, repudia e age contrariamente ao que lhe foi ensinado pela experiência e pela razão. Donde Hobbes (idem:15-16) conclui que

“[...] a menos que, dizendo que os homens são maus por natureza, entendamos apenas que eles não recebem da natureza a sua educação e o uso da razão, deveremos necessariamente reconhecer que os homens possam derivar da natureza o desejo, o medo, a ira e outras paixões, sem contudo imputar seus maus efeitos à natureza".

Portanto, quando Hobbes se refere à natureza humana, não devemos tomar seus atributos como dizendo respeito a cada um dos indivíduos (mas sim a parcela significativa da população humana), nem tomá-los como totalmente responsáveis pela má conduta dos indi- 


\section{Argumentos para uma Dissociação da}

Filosofia Política de Thomas Hobbes...

víduos. Isso porque estava consciente de que o que determina o comportamento das pessoas é, acima de tudo, a forma como são educadas (Gert, 1996:166). Aqui, de maneira alguma, devemos deixar de reconsiderar aquela competitividade que emerge no estado de natureza em virtude da escassez e da incerteza dos meios necessários para a garantia da segurança do indivíduo em tal estado (o que o leva a maximizar suas conquistas). Essa competitividade natural, porém, seria para Hobbes facilmente resolvida pelo avanço da ciência e do progresso (Freyberg-Inan, 2004:52) ${ }^{22}$. Na verdade, como Tuck ressalta em sua introdução ao Leviatã, Hobbes não tomava a escassez de recursos como algo notável em sua época, remetendo, portanto, a natureza dos conflitos não aos interesses, e sim às crenças (Tuck, 1996:xxvii): “[...] existe agora e sempre existiu uma guerra de espíritos no que se refere a opiniões e sentimentos, e [...] esta guerra é exatamente como o estado de natureza" (Hobbes apud Tuck, 1996:xxx).

Em outro trabalho, porém, o mesmo autor afirma que não há distinção válida, em Hobbes, entre crenças e interesses (Hobbes apud Tuck, 1996:185), e isto nos parece uma alternativa mais razoável na medida em que vai ao encontro do que Skinner identifica como a "descoberta hobbesiana fundamental": a de que "[...] os interesses contaminam a formação das crenças, dando origem a uma disposição de questionar até mesmo as verdades mais palpáveis da razão, quando os interesses e a razão entram em choque" (Skinner, 1999:464). Hobbes deixa isso bastante claro quando afirma que, estando a razão contra os interesses dos indivíduos, estes se voltarão, normalmente, contra ela.

"É essa a causa em razão da qual a doutrina do bem e do mal é objeto de permanente disputa, tanto pela pena como pela espada, ao passo que com a doutrina das linhas e figuras o mesmo não ocorre, dado que aos homens não preocupa qual é a verdade neste último assunto, como coisa que não se opõe à ambição, ao lucro ou à cobiça de ninguém. Pois não duvido que, se acaso fosse contrária ao direito de domínio de alguém, ou aos interesses dos homens que possuem domínio, a doutrina segundo a qual os três ângulos de 
Iara Costa Leite

um triângulo são iguais a dois ângulos de um quadrado teria sido, se não objeto de disputa, pelo menos suprimida, mediante a queima de todos os livros de geometria, na medida em que os interessados fossem capazes de tal coisa" (Hobbes, 1996:73-74, ênfases no original).

Não obstante, pode-se dizer que, ao culpar as convenções formadas a partir de doutrinas perversas e errôneas pela conduta inadequada dos indivíduos - quer dizer, pela prevalência dos interesses individuais sobre a razão ou, antes, pela própria discrepância de conteúdo entre eles -, e não as necessidades impostas pela natureza humana, Hobbes torna-se um pensador bem mais otimista que os realistas clássicos. Embora, como nos mostra a passagem supracitada, o filósofo demonstre um ceticismo notável com relação ao poder da razão perante os interesses, esse problema não permanece sem resposta, na medida em que diz respeito não à recorrência à força, mas à utilização dos mesmos meios pelos quais se interiorizaram as opiniões correntes dos indivíduos: o tempo e a educação (Hobbes, 1999:176) ${ }^{23}$.

É importante deixar em evidência que subjacente à identificação do ensino como meio eficiente de transformação das concepções e atitudes dos indivíduos está um pressuposto cujo caráter otimista é inegável: o de que a mente humana é indefinidamente maleável (Hanson, 1984:339). Assim nos diz Hobbes (1999:176-177):

“[...] não há dúvida de que se a verdadeira doutrina concernente à lei da natureza, às propriedades do corpo político e à natureza do direito em geral fosse estabelecida de forma perspícua e ensinada nas universidades, aqueles jovens homens, que lá se apresentam isentos de preconceito, e cujas mentes ainda são papel branco, capazes de qualquer instrução, receberiam mais facilmente a própria, e posteriormente a ensinariam às pessoas, tanto em livros quanto por outros meios [...]".

A partir da discussão acima podemos concluir que os interesses individuais não são naturalmente depositários das qualidades racionais necessárias à realização do desejo natural pela sobrevivência, pois são contaminados, um tanto quanto paradoxalmente, por um atributo também natural (embora seja adquirido seu conteúdo específico), e 


\section{Argumentos para uma Dissociação da}

Filosofia Política de Thomas Hobbes...

que define o homem enquanto tal: a fala (Hobbes, 1996:24). O problema é que, por seu uso incorreto - seja pela imposição arbitrária de nomes, seja pelos costumes (Hanson, 1984:343) - e diversificado dada a multiplicidade de paixões -, são gerados padrões de conduta instáveis e contraditórios, que acabam por levar os indivíduos a definirem seus interesses de forma inconstante, o que, em última instância, torna imprevisíveis suas atitudes e conflituosas suas relações. A proposta de Hobbes é que sigamos a natureza, pois ela não erra. E sua lei fundamental é a de que busquemos a paz e, quando isso não for possível, que nos defendamos, e em ambos os casos o bem supremo diz respeito ao mais "natural" (e, por conseguinte, racional e moral) de todos os desejos: a busca da autopreservação.

Note-se, porém, que a prevalência da razão sobre as paixões excessivas, quer dizer, a definição dos interesses a partir da consideração primeira das questões relacionadas à sobrevivência, é algo a ser construído (tanto com relação aos indivíduos, quanto aos soberanos) e não, como estabelece o neo-realismo, um pressuposto empírico ${ }^{24}$. Nesse sentido, a seguinte pergunta pode emergir: se a racionalidade baseada no auto-interesse não é algo empiricamente observável, como foi possível a realização do contrato entre os indivíduos? A questão é que, como procurei demonstrar nesta seção, este contrato, bem como o reducionismo motivacional que o fundamenta, diz respeito não a um dado real, mas a uma hipótese cujas premissas e consequiências devem ser interiorizadas pelos atores do processo político (influenciando desde a formação homens comuns até os tomadores de decisão) caso o fim buscado seja a ordem (doméstica e, como veremos na seção seguinte, até mesmo internacional). Em suma:

"O contrato hobbesiano não é um evento cuja realidade - histórica ou lógica - deva ser contestada por Hobbes. Ele não está esboçando uma teoria empírica sobre como as sociedades surgiram, mas antes delineando o que acredita serem os termos para o pensamento correto sobre a política, e elucidando os princípios sobre os quais os Estados devem ser estruturados. [...] As sociedades e os governos, Hobbes parece inferir, podem ter surgido historica- 
Iara Costa Leite

mente mediante todos os tipos de idéias equivocadas e falsas, mas enquanto permanecerem fundados sobre tais idéias eles serão inerentemente instáveis e fadados à desavença, tumulto e colapso. Apenas a reconstrução de tais sociedades segundo os caminhos demonstrados pelo próprio Hobbes e em virtude dos problemas que delineia pode servir para evitar esse destino desastroso" (Williams, 1996:226, ênfase no original).

Fica patente, portanto, que o modelo do estado de natureza hobbesiano tem como tarefa central não a descrição da realidade, mas sua transformação $^{25}$. À primeira vista, pode parecer que, tendo dedicado seus estudos à descoberta dos preceitos que deveriam pautar a vida civil, Hobbes exclua de suas preocupações a paz e a guerra entre as nações. Não obstante, a incipiente consolidação de uma autoridade central nos moldes do Estado moderno, em sua época, nos faz crer que, sendo obscura a linha divisória entre interno e externo, o que ocorria ou viria a ocorrer em um domínio tinha impactos diretos sobre o outro (se é que um dia o deixou de ter). Destinarei a próxima seção à exploração desse argumento.

\section{O internacional como domínio extensivo à configuração da ordem doméstica}

Um dos questionamentos centrais da analogia entre as relações internacionais e as relações entre os indivíduos no estado de natureza, levada a cabo pelo realismo, provém da Escola Inglesa (Williams, 1996:214). A hipótese que norteia a problematização dessa analogia é a de que, se Hobbes não realizou extensão lógica de seu argumento da necessidade de um contrato entre os indivíduos para a esfera internacional, é porque não a considerava como dotada daquela insustentabilidade detectada na condição natural dos homens. Isso porque, segundo Bull, as características atribuídas aos indivíduos e a seu ambiente natural - o fato de serem igualmente vulneráveis, a necessidade de direcionamento total de seus atributos físicos e mentais à busca 


\section{Argumentos para uma Dissociação da}

Filosofia Política de Thomas Hobbes..

de segurança (não podendo haver, portanto, indústria, agricultura, navegação, comércio etc.) e a ausência de regras morais - não se verificam nas circunstâncias internacionais. Aqui, embora a postura de guerra seja conspícua, as unidades: (1) não direcionam seus esforços apenas para a segurança física, garantindo também, domesticamente, a realização de atividades fundamentais para o desenvolvimento e bem-estar dos cidadãos; (2) são consideravelmente menos vulneráveis que os indivíduos a ataques repentinos e violentos ${ }^{26}$; (3) não são igualmente vulneráveis, havendo uma disparidade de poder significativa entre grandes e pequenas potências; e, finalmente, (4) são mais auto-suficientes que os indivíduos, podendo, portanto, tolerar formas sociais mais frouxas (Bull, 1966:45-47) ${ }^{27}$.

Posteriormente, Bull empenha-se na contestação da noção de que não há moral no estado de natureza, afirmando que o que não se observa é a existência de leis positivas, mas que se fazem presentes leis emanadas de Deus: as chamadas leis da natureza. Estas leis se convertem, na esfera doméstica, em leis civis e, na internacional, em um direito das gentes (Law of Nations), que diz respeito a regras prudenciais de sobrevivência que guiam os Estados em suas relações uns com os outros (Bull, 2000). Esse raciocínio se confirma em diversos trechos da obra de Hobbes, e podemos citar como exemplo o seguinte:

“[...] o direito das gentes e a lei da natureza são uma e a mesma coisa. E qualquer soberano tem o mesmo direito, ao procurar a segurança de seu povo, que qualquer homem privado precisa ter para conseguir a segurança de seu próprio corpo. E a mesma lei que dita aos homens destituídos de governo civil o que devem fazer e o que devem evitar no que se refere uns aos outros dita o mesmo aos Estados, isto é, às consciências dos soberanos príncipes e das assembléias soberanas, não havendo nenhum tribunal de justiça natural, exceto na própria consciência, na qual não é o homem que reina, mas Deus, cujas leis (como as que obrigam toda a humanidade) no que se refere a Deus, na medida em que é o autor da natureza, são naturais, e no que se refere ao mesmo Deus, na medida em que é rei dos reis, são leis" (Hobbes, 1996:244, ênfases no original). 
Embora essas leis sejam imperfeitas, pois que obrigam, em virtude da ausência de um poder coercitivo central, apenas in foro interno, não deixam de constituir, segundo Bull, uma fundação comum para a coordenação das relações interestatais:

"Mesmo sendo imperfeitas, essas leis da natureza, 'os artigos de paz' como Hobbes as chama, são a linha de conduta que os Estados soberanos na anarquia internacional devem abraçar caso queiram sobreviver" (Bull, 2000:198).

O que Bull deseja demonstrar, ao falar da importância que essas regras da razão natural desempenham (ou deveriam desempenhar) na condução à paz, é que, ao contrário da imagem hobbesiana divulgada pelo realismo - centrada, entre outras coisas, em uma visão de que qualquer coisa é permissível em um ambiente anárquico -, a abordagem de Hobbes a respeito das relações internacionais, pelo menos se partirmos de suas fundações - as leis da natureza -, é profundamente pacífica (pois não deixa de estabelecer limites, embora imperfeitos, à condução da política internacional).

Uma crítica significativa à possibilidade de qualquer nível de eficácia das leis da natureza na ordenação das relações entre os indivíduos e Estados provém do fato de que, embora identificado o desejo pela autopreservação e o medo da morte violenta como solução para a ausência de padrões morais objetivos, permanece ainda outro problema: a indeterminação epistêmica. Segundo Michael Williams (1996:218), mesmo sendo as leis da natureza universais, eternas e acessíveis a todos, os indivíduos, em virtude da particularidade de suas percepções, não atribuem o mesmo sentido a elas, sendo o julgamento do soberano fundamental na estabilização de seu conteúdo. O mesmo relativismo epistemológico é verificado na esfera internacional, daí o auto-interesse e o medo não se confirmarem como bases eficazes na coordenação das ações entre soberanos (idem:228). 


\section{Argumentos para uma Dissociação da}

Filosofia Política de Thomas Hobbes...

Se a fonte do conflito no estado de natureza remete a uma ausência de verdade, e não simplesmente da centralização da força, pode-se dizer que, mesmo ocorrendo esse último processo, quer dizer, mesmo resolvido o problema do acesso livre aos meios materiais de destruição mútua na esfera doméstica, esta ainda assim permanece frágil e suscetível à erosão interna caso o soberano deixe de cumprir sua tarefa de definição e difusão dos direitos essenciais dos cidadãos (o que constitui, segundo Hobbes, não a exceção, mas a regra): “[...] os fundamentos desses direitos devem ser ensinados de forma diligente e verdadeira, porque não podem ser mantidos por nenhuma lei civil, ou pelo terror de uma punição legal" (Hobbes, 1996:232). Quer dizer, a única forma de uma comunidade civil ter plenamente assegurada a ordem é se as fundações da autoridade moral do soberano, bem como as consequiências de sua dissolução, forem transmitidas e interiorizadas pelos cidadãos mediante ensino. Ou seja, a obediência passa a ser função, principalmente, da legitimidade (Williams, 1996:220) ${ }^{28}$.

Mas, afinal, qual é o impacto da fragilidade da ordem doméstica na configuração da ordem na esfera internacional? Um dos autores que nos fornecem a resposta para essa pergunta é o próprio Bull (que, curiosamente, deixa de extrair do argumento maiores implicações):

"Na época de Hobbes, como na nossa, conflitos civis e interestatais estavam intimamente relacionados uns com os outros: guerras civis criavam oportunidades para intervenções estrangeiras, e lealdades religiosas, como as lealdades a religiões seculares atualmente, ligavam as facções através das fronteiras" (Bull, 2000:191).

O que Bull deixa de notar é que a resolução desses conflitos, para Hobbes, não depende apenas da autolimitação, segundo as leis da natureza, da conduta dos soberanos (o que seria verdadeiro se as causas da guerra tivessem como fonte primária conflitos interestatais de interesses e de objetivos), mas baseia-se em um legado clássico (formado pelo pensamento de Tucídides, Platão, Aristóteles e Santo Agostinho, entre outros) segundo o qual, remetendo-se as causas úl- 
timas das guerras (domésticas ou internacionais) às disposições individuais, somente sanando as paixões humanas excessivas - no caso de Hobbes, notadamente o orgulho, daí intitular o Leviatã de King of the Proud (Hobbes, 1996:221) - e eliminando a ignorância generalizada com relação às causas da guerra e da paz ${ }^{29}$, há possibilidade de se estabelecer a ordem (Hanson, 1984:338, 343) ${ }^{30}$.

O postulado de que os soberanos têm sua liberdade de ação limitada, na esfera internacional, apenas pelo resultado da configuração de suas capacidades materiais em relação aos outros, tem como contrapartida implícita a crença de que sua autoridade na esfera doméstica está plenamente assegurada pelo monopólio do uso da força, e que quaisquer demandas internas, caso se afastem das demandas identificadas pela "razão de Estado", podem ser facilmente caladas pela coerção. Em outras palavras: a crença de que a conduta dos soberanos é determinada tão somente pela anarquia internacional tem como pano de fundo o que seria uma completa ausência de obrigações para com os cidadãos, já que estas parecem ser tidas como reais apenas quando as unidades são ameaçadas por uma força superior. Não devemos negar que esse raciocínio parece ter respaldo, pelo menos em parte, em Hobbes, já que este deixa claro, em alguns trechos de sua obra, que a moralidade depende da coerção e que, sendo as ações injustas aquelas que deixam de cumprir um contrato, e sendo este realizado entre indivíduos, e não entre estes e os soberanos, nenhuma decisão tomada por estes últimos pode ser tida como propriamente injusta - embora Hobbes acrescente que, quando os atos do soberano infringem danos à população, significam uma transgressão da lei da natureza, bem como da lei divina (Hobbes, 1999:172).

$\mathrm{Na}$ verdade, o que garante a ordem na esfera internacional, para Waltz, é o fato de a conduta dos Estados ser limitada não puramente pela anarquia internacional, mas pelo pressuposto de que eles buscam a sobrevivência - o que significa que, a partir de um cálculo racional da distribuição estratégica das capacidades, abster-se-ão de en- 


\section{Argumentos para uma Dissociação da}

Filosofia Política de Thomas Hobbes...

gajar-se em uma busca ilimitada pelo poder caso isso venha a colocar em risco sua sobrevivência (o que se converte em regra, já que as capacidades materiais de um Estado raramente são superiores à soma das capacidades alheias). Hobbes, porém, da mesma forma que não enxerga no indivíduo uma potência natural da razão sobre os interesses, não deixa de admitir que também o soberano, embora se constitua como pessoa artificial (pois que representante de uma nação), por ser também pessoa natural individual, encontra-se suscetível à busca de seus interesses particulares (provenientes das paixões) ${ }^{31}$, os quais, chocando-se com o interesse público, normalmente prevalecerão sobre ele (Skinner, 1999) ${ }^{32}$.

Não obstante, os soberanos têm tarefas (duties) fundamentais a cumprir, e elas não se centram apenas na defesa contra agressões externas, mas, antes, no esforço de evitar que os desígnios de outros soberanos encontrem respaldo na insatisfação doméstica. Para Hobbes, a "Lei Geral dos Soberanos" baseia-se na realização do dito salus populi suprema lex ${ }^{33}$, que consiste na multiplicação da espécie, nas comodidades da vida (as quais incluem ausência de proibições desnecessárias e geração de riqueza mediante comércio, trabalho e proibição do consumo de bens supérfluos), na paz entre os cidadãos (pelo estabelecimento de propriedades, cobrança proporcional de impostos, execução da justiça, incentivo à modéstia, punição pública dos ambiciosos e eliminação de opiniões sediciosas pelo ensino) e na defesa contra agressão externa. Neste último caso, além da obediência e união dos súditos (com o fim de se levantar e direcionar o dinheiro, homens, armas etc. necessários à defesa) é também condição sine qua non que sejam evitadas guerras desnecessárias:

"Aquelas nações, bem como aqueles monarcas, que anseiam pela guerra por ambição ou vanglória, ou que revidam cada pequena injúria ou difamação realizada por seus vizinhos, se não arruinarem a si próprias, é porque sua fortuna deve ser maior do que têm razão em presumir" (Hobbes, 1999:177). 
É importante ressaltar, ainda, que as segunda e terceira tarefas a serem realizadas pelo soberano apresentam também relação de causalidade com o estabelecimento da ordem internacional. A educação, por exemplo, engendra legitimidade à moral definida pelo soberano, e contribui para diminuir a intensidade de ambições políticas domésticas que possam resultar em conspirações com potências estrangeiras; a abundância material, por sua vez, pode remover impulsos econômicos imperialistas (Hanson, 1984:348-349).

Por fim, realizadas todas as tarefas acima citadas, o soberano fortalece a união interna e, por conseguinte, seu poder absoluto, o que impede que a hostilidade de outros Estados - "[...] os quais [...] não perderão uma ocasião de enfraquecer o domínio dos seus vizinhos" (Hobbes, 1996:222, ênfase no original) - torne-se efetiva ${ }^{34}$. Daí a hipótese avançada por Hanson, em artigo intitulado "Hobbes's Highway to Peace", de que "Estados delineados segundo os moldes do Leviatã podem, no mínimo, ser por si próprios consistentes com a paz geral da humanidade e, no máximo, suprir alguma expectativa de assegurá-la" (Hanson, 1984:334).

Pode-se perguntar, nesse contexto, e com base no que já foi dito anteriormente, o que garante, sendo o soberano a autoridade suprema, que suas tarefas sejam realizadas. A resposta para essa questão reside, segundo Williams, na inalienabilidade do direito de autopreservação, havendo, portanto, direito de rebelião caso os indivíduos julguem ameaçada sua sobrevivência:

"Entende-se que a obrigação dos súditos para com o soberano dura enquanto, e apenas enquanto, dura também o poder mediante o qual ele é capaz de protegê-los. Porque o direito que por natureza os homens têm de defender-se a si mesmos não pode ser abandonado por meio de pacto algum" (Hobbes, 1996:153).

Isso significa que, deixando os soberanos de cumprir as tarefas ditadas pelo salus populi suprema lex, estarão colocando em ameaça a sobrevivência e o bem-estar dos súditos e, em última instância, a or- 


\section{Argumentos para uma Dissociação da}

Filosofia Política de Thomas Hobbes...

dem civil que garante sua autoridade. É justamente a fragilidade dessa ordem e das relações políticas que estabelece, bem como a consciência das consequiências desastrosas que sua destruição acarretaria, que fariam com que tanto súditos quanto soberanos compreendessem e agissem segundo os limites práticos e prudenciais impostos pelas circunstâncias (Williams, 1996:221). Neste sentido,

"O soberano, reconhecendo as fundações de sua autoridade, deve ser cauteloso a fim de não perder a confiança dos cidadãos. [...] Já que eles [os soberanos] devem definitivamente convencer os cidadãos a obedecer a seus julgamentos de ameaça (e portanto convencer os próprios cidadãos a ir à guerra ou a ajudar nos preparativos para ela), o soberano prudente será cauteloso em lançar-se à prática por medo de perder a confiança dos cidadãos no seu julgamento (da mesma forma que não deve oprimir os cidadãos desnecessariamente pelo mesmo motivo), o que poderia estimulá-los à dissensão ou rebelião" (idem:232).

Aqui, temos por conseguinte que aquela analogia entre as relações individuais, no estado de natureza, e interestatais, na anarquia, novamente se dissolve. Embora não se possa verificar um poder centralizado e legítimo na esfera internacional, os soberanos não poderão agir da mesma forma que os indivíduos no estado de natureza porque devem considerar a vinculação entre as relações externas (soberano-soberano) e as internas (soberano-cidadãos). Suas relações são limitadas, portanto, não apenas pelas suas capacidades, mas também pelos constrangimentos práticos da construção doméstica ${ }^{35}$. Donde Williams (idem: 223-224) conclui que

“[...] o poder estatal não é simplesmente recurso de uma capacidade objetiva. Para Hobbes, é resultado da resolução de problemas e dilemas fundamentais na construção de uma ordem política potencialmente frágil e contingente. A existência e exercício do poder estatal, portanto, não podem ser, para Hobbes, vistos isoladamente dos constrangimentos e considerações adjacentes à sua gênese e legitimidade permanente".

O que Williams deixa de admitir - talvez em virtude de fazer parte de uma época em que o divino represente um papel completamente in- 
significante na esfera acadêmica e uma fonte explicativa impotente (para não dizer hilária) perante os argumentos realistas que a norteiam-é que todo esse processo de limitação da conduta do soberano e dos súditos por ele descrito tem como força motriz, para Hobbes, nada menos que o reino natural de Deus sobre os homens - reino este cuja potência engendra não apenas leis naturais, mas também punições naturais:

"Não existe nesta vida nenhuma ação do homem que não seja o começo de uma cadeia de conseqüências tão longa que nenhuma providência humana é suficientemente alta para dar ao homem um prospecto até o fim. E nesta cadeia estão ligados acontecimentos agradáveis e desagradáveis, de tal maneira que quem quiser fazer alguma coisa para seu prazer tem de aceitar sofrer todas as dores a ele ligadas; e estas dores são as punições naturais daquelas ações que são o início de um mal maior que o bem. E daqui resulta que a intemperança é naturalmente castigada com doenças, a precipitação com desastres, a injustiça com a violência dos inimigos, o orgulho com a ruína, a covardia com a opressão, o governo negligente dos príncipes com a rebelião, e a rebelião com carnificina. Pois uma vez que as punições são conseqüentes com a quebra das leis, as punições naturais têm de ser naturalmente conseqüentes com a quebra das leis da natureza e, portanto, seguem-se como seus efeitos, naturais e não arbitrários" (Hobbes, 1996:253-254).

Independentemente da origem da cadeia de conseqüências das escolhas humanas, o que se pode notar, a partir das considerações realizadas nas últimas páginas, é que o nacional e o internacional constituem, na obra de Hobbes, domínios coextensivos e mutuamente controladores. Mesmo que o soberano conquiste e mantenha um monopólio físico da força, suas decisões jamais podem deixar de ter respaldo na opinião dos súditos, já que estes, uma vez insatisfeitos, podem ser auxiliados por um soberano externo interessado em novas conquistas $^{36}$. Quer dizer, a liberdade de todos a tudo, na esfera internacional, constituiria, em última instância, um importante "mecanismo" de controle do desempenho interno das atividades soberanas baseadas no salus populi suprema lex. 


\section{Argumentos para uma Dissociação da}

Filosofia Política de Thomas Hobbes...

Curiosamente, essa interpretação de Hobbes parece aproximar-se mais da noção construtivista baseada no enunciado "anarchy is what states make of it" (Wendt, 2000) - uma vez que a ocorrência de conflitos internacionais estaria atrelada à decisão do soberano em desempenhar ou não suas tarefas domésticas - do que na qualidade perene e necessária da anarquia internacional como estado de natureza.

\section{Conclusão}

O propósito deste artigo foi o de desenvolver, a partir de uma cuidadosa leitura da obra de Hobbes, argumentos que problematizam sua confluência com uma suposta "tradição realista" das relações internacionais. Embora tanto os realistas quanto seus críticos tomem como óbvia a associação da analogia entre anarquia internacional e estado de natureza com o nome de Thomas Hobbes, poucos estudos vêm sendo direcionados para confirmar ou refutar a unidade entre o pensamento do filósofo e sua imagem prevalecente entre os estudantes de relações internacionais.

Tendo resgatado o caráter hipotético desse modelo, bem como o fato de Hobbes não ter mencionado a necessidade de instituição de um governo mundial, restaram-me duas possibilidades (que não deixam de ser complementares) para o tratamento das relações internacionais na filosofia política de Hobbes: existe uma inconsistência no argumento do filósofo por ter dado como exemplo de algo que nunca existiu a relação entre os Estados (embora ele aborde como exemplo maior as próprias circunstâncias internas de seu país); e/ou não devemos deduzir que tudo o que o filósofo disse sobre a condição natural dos homens seja válido para a explicação da relação entre os Estados.

Minha hipótese foi a de que o que tornava conflituosa a relação entre os Estados, em Hobbes, poderia não ser apenas a liberdade de todos os soberanos a tudo, ou a inexistência de um poder superior que controlasse suas atividades, mas a inexistência de ordens domésticas su- 
ficientemente consolidadas - não apenas no que diz respeito à centralização do poder, mas especialmente no que se refere à legitimidade do governo do soberano perante a população - para impedir que os desígnios de alguns soberanos encontrassem respaldo na insatisfação dos diversos setores sociais. Este problema, segundo Hobbes, não seria passível de resolução apenas pela ameaça soberana do uso da força, mas por um desempenho integral das tarefas dos soberanos com relação aos súditos - inclusive o estabelecimento de ideais de ensino que demonstrassem a obrigatoriedade da obediência pela sua legitimidade. Quer dizer, o comando do soberano só seria eficiente caso os súditos tivessem interiorizados como opiniões próprias os propósitos da autoridade central e as causas e consequiências de sua dissolução.

Assim, estariam eliminadas ambas as sementes da mortalidade da soberania: a prevalência das paixões sobre a razão (causada pela ignorância) e, em grande medida, as invasões internacionais, porque estas, uma vez unida a população em torno de ideais comuns, dificilmente ocorreriam. Note-se, porém, que dificilmente não significa nunca; afinal, Hobbes acredita que também os soberanos, como pessoas naturais, estão suscetíveis a ações irracionais.

As questões levantadas neste artigo se inserem em um debate contemporâneo mais amplo, todavia ainda incipiente, que tem como bojo a transposição da amnésia das origens filosóficas da noção realista de anarquia internacional (e de outros elementos que constituem a base dos nossos entendimentos disciplinares), seja pela desconsagração de obras dadas como pertencentes à "tradição realista", seja pela elaboração mais cuidadosa de histórias conceituais que resgatem outras raízes que não as normalmente veiculadas pelo mainstream do estudo das relações internacionais. Ao problematizar a analogia entre relações internacionais e estado de natureza pela introdução de interpretações dissidentes do pensamento de Thomas Hobbes, coloco em dúvida a unidade entre seus pressupostos e propósitos e os 


\section{Argumentos para uma Dissociação da}

Filosofia Política de Thomas Hobbes...

veiculados pelo realismo. Em última instância, isso aponta para a fragilidade dos alicerces conceituais em que se assenta essa teoria.

Não obstante, a conclusão a que cheguei foi a de que as considerações de Hobbes a respeito das relações internacionais, por ocuparem lugar marginal em sua obra, são breves, pontuais e contraditórias, o que torna diletante e anacrônico, pelo menos se tivermos como objetivo um mínimo de fidedignidade em relação ao seu pensamento, qualquer tentativa de conferir a tais considerações um caráter sistemático que possa vir a contribuir para o desenvolvimento teórico e analítico de nossa disciplina. Contudo, a leitura de Hobbes não deixa de constituir tarefa essencial para os estudantes das relações internacionais, não porque dela possam ser extraídas lições sobre a anarquia internacional, mas para que se perceba o quanto elas são obtusas.

\section{Notas}

1. Essas premissas nos dizem que, em um sistema internacional anárquico, as unidades territoriais são os atores centrais, racionais, que calculam seus interesses em termos de poder (Keohane, 1993:190).

2. Ver, por exemplo, Flathman (1993), Borot (1996), Gert (1996), Sorell, (1996), Zarka (1996) e Skinner (1999).

3. Nas palavras de Skinner (1999:28), “[...] pensar na prosa hobbesiana como uma janela clara, através da qual podemos fitar ininterruptamente seu pensamento, constitui um grave erro" (1991:154). Nas de Oakeshott (apud Hanson, 1984:334-335), “[...] toda interpretação da teoria moral de Hobbes deixa algo que Hobbes escreveu imperfeitamente avaliado". Até mesmo nas de Bobbio (1991:154): "Hobbes é um pensador muito complexo, apesar da aparente simplicidade da sua teoria; ambíguo, apesar da aparente clareza; bastante tortuoso, apesar da aparente linearidade".

4. Farei uma exposição breve do contexto do Leviatã porque foi ele, ou melhor, um de seus capítulos (o XIII) que se converteu em "livro-texto" na disciplina de relações internacionais. 
lara Costa Leite

5. É possível que o apreço que Hobbes tinha pelo seu próprio sistema de pensamento e pelas suas descobertas não tenha sido uma atitude verdadeiramente honesta, mas uma arma de retórica e convencimento.

6. Para esclarecimentos quanto ao caráter profético da consideração realista dos pressupostos e implicações da anarquia internacional, ver Freyberg-Inan (2004).

7. Essas categorias taxonômicas que incluem o pensamento de Hobbes em uma tradição realista foram lançadas e difundidas pelos trabalhos de Martin Wight (Navari apud Freyberg-Inan, 2004:190, nota 8). Porém, é importante ressaltar que, em Why Is There No International Theory?, Martin Wight deu início à dissociação de Hobbes da perspectiva realista ao refutar a identificação da relação entre os Estados com a situação pré-contratual do estado de natureza a partir da constatação da inconsistência desse argumento no próprio pensamento de Hobbes. Referindo-se a este filósofo, afirma: "Ele descreve o estado de natureza, quando os homens convivem na ausência de um poder superior para mantê-los intimidados, como uma condição de guerra de todos contra todos; e, açambarcando o argumento de que tal condição jamais existiu, aponta as relações entre Estados soberanos como forma de exemplificá-la. Porém, acrescenta esta frase: 'Mas como por meio disso protegem a indústria de seus súditos, daí não advém como conseqüência aquela miséria que acompanha a liberdade dos indivíduos isolados'. Isto é empiricamente verdadeiro" (Wight, 1966:31). Não obstante, em International Theory, Wight reafirma aquele vínculo ao incluir o filósofo sob o "maquiavelismo" da tradição realista (Almeida, 1999). Em busca da construção de uma tradição racionalista da teoria internacional, cujas fontes remeteriam a Locke ou Kant, Wight acaba por enxergar em Hobbes muito pouco além do apresentado pela interpretação realista: "O estado de natureza é uma guerra de todos contra todos, e a resposta para a pergunta 'O que é sociedade internacional?' é 'Nada'” (Wight, 1991:31). Nesse sentido, Wight dispensa qualquer contribuição da obra de Hobbes para a realidade internacional que deseja explorar - a da sociedade internacional.

8. Contra esse tipo de atitude, aliás, advertia o próprio Hobbes (1996:415), referindo-se à Escritura: "Pois não são as palavras nuas, mas sim o objetivo do autor que dá a verdadeira luz pela qual qualquer escrito deve ser interpretado, e aqueles que insistem nos textos isolados, sem considerar o desígnio principal, nada deles podem tirar com clareza, mas antes jogando átomos nas Escrituras como poeira nos olhos dos homens, tornam tudo mais obscuro do que é, artifício habitual daqueles que não procuram a verdade, mas sim suas próprias vantagens".

9. Cabe ressaltar que existem outras respostas para a pergunta em questão. Gregory Kavka (1983:305), por exemplo, afirma que a criação de um estado 


\section{Argumentos para uma Dissociação da}

Filosofia Política de Thomas Hobbes...

mundial geraria uma dificuldade na coordenação de ações e de crenças: “Quanto maior o grupo, maior o potencial para o conflito interno, como também é provável que haja maior variação de crenças e valores entre os membros e menor coesão coletiva baseada em ligações pessoais".

10. Esta autora qualifica o argumento em questão: “Os realistas não afirmam normalmente que os pressupostos que usam para simplificar e representar a complexa realidade da motivação humana estejam 100\% corretos. Porém, consideram-nos como sendo uma aproximação suficiente dessa realidade para prover suas teorias e modelos com uma base axiomática defensável para o desenvolvimento de explicações plausíveis e previsões razoáveis exatas" (Freyberg-Inan, 2004:5-6).

11. Esse é o argumento central do nominalismo. Para um aprofundamento acerca dessa corrente filosófica, ver Armstrong (1978). Agradeço a Rob Walker por ter me chamado a atenção para o fato de que, embora em virtude de seu pessimismo Hobbes tenha ganho reputação de ser realista, seu nominalismo vem primeiro. Como veremos adiante, até mesmo o pessimismo hobbesiano pode, em certa medida, ser negado.

12. Isso significa que, ao contrário do realismo que tem como pressuposto a capacidade da mente humana em descobrir a essência dos fatos, "[...] semelhantemente aos pós-empiricistas contemporâneos, Hobbes nega a asserção de que os fatos a partir dos quais as teorias são construídas estão indiscutivelmente dados" (Williams, 1996:224). Na verdade, a epistemologia hobbesiana, ao afirmar a impossibilidade de se atingir o conhecimento por meio de observações (tendo em vista a natureza radicalmente particular e arbitrária do observador), afasta-se do pensamento aristotélico mais geral que toma as coisas como sendo naturalmente inteligíveis a nós (Flathman, 1993:15-16).

13. Segundo Skinner (1999:397), “[...] Hobbes está longe de ver a recta ratio, nos termos tradicionais, como uma intuição ou faculdade infalível”.

14. Não obstante, isso não significa que o desejo pela autopreservação seja algo observável no comportamento dos indivíduos. Como veremos, trata-se, antes, de uma abstração cujo propósito é se dissociar da desordem real.

15. Em introdução ao livro Behemoth or the Long Parliament, Stephen Holmes afirma ter a impressão de que Hobbes, em sua análise da guerra civil que devastou a Inglaterra entre 1640 e 1660, demonstra que "os seres humanos são, antes de tudo, incapazes de raciocínio prudente e, em segundo lugar, estupidamente indiferentes à autopreservação" (Holmes apud Freyberg-Inan, 2004:47). Isto fica bem claro na seguinte passagem: "Todo homem por natureza (sem disciplina) olha em todas as suas ações, tanto quanto possa divisar, o benefício que a si 
lara Costa Leite

mesmo redundará de sua obediência. Lê que a cobiça é a raiz de todo o mal, mas pensa, e às vezes descobre, que é a raiz de suas posses. E assim também em outros casos, em que as Escrituras dizem uma coisa e ele pensa outra, pois pesa apenas as conveniências e inconveniências de sua vida presente, que está diante de seus olhos, e nunca põe na balança o bem e o mal da vida futura, que não divisa" (Hobbes, 2001:93).

16. Isso fica perfeitamente claro quando Hobbes (2002:31, ênfases minhas) afirma que "[...] todo homem é desejoso do que é bom para ele, e foge do que é mau, mas acima de tudo do maior dentre todos os males naturais, que é a morte; e isso ele faz por um certo impulso da natureza, com tanta certez a como uma pedra cai". Como nota Skinner (1999:425), a busca da paz no estado de natureza, em nome da autopreservação, "[...] constitui, ao mesmo tempo, uma reação natural e uma reação instigada por nossa capacidade de antever as conseqüências indesejáveis de nosso comportamento irrefreado".

17. Embora afirme que o desejo mútuo de se ferirem provém, mais freqüentemente, de apresentarem os homens apetites pelas mesmas coisas, Hobbes (2002:30) afirma que tal desejo se manifestará mais intensamente quando resultante de humilhações.

18. Quando se refere a essas querelas intelectuais, Hobbes (2001:105), expressa a incapacidade do Estado em eliminar o orgulho da esfera doméstica: "Um Estado pode constranger à obediência, mas não convencer de erros, ou alterar os espíritos dos que crêem ter a melhor razão".

19. "Assim, entre tantos perigos com que os desejos (lusts) naturais dos homens diariamente os ameaçam, cuidar de si mesmo não é uma questão que deva ser considerada com tanto desdém, como seria se não houvesse em nós poder e vontade para agir de outro modo" (Hobbes, 2002:31).

20. J. C. A. Gaskin, em sua introdução ao livro Human Nature and De Corpore Politico, deixa claro que Hobbes não exclui a possibilidade de a benevolência fazer parte das motivações humanas: "[...] pelo menos algumas vezes, agir de acordo com a aversão à dor (em um sentido amplo) ou com o desejo por prazer inclui evitar o desconforto em agir mal com relação a outras pessoas". Como Hobbes (1999:15) afirma, existe um prazer especial em dar prazer aos outros. Ele não desenvolve essa observação, mas ela aponta para o caminho que depois foi trilhado por Shaftesbury e Hume, qual seja, de que a benevolência, ou o júbilo em dar alegria aos outros, é uma motivação humana básica que acompanha o auto-interesse, embora não o explique de maneira conclusiva (Gaskin, 1999:xxxiv-xxxv). 


\section{Argumentos para uma Dissociação da}

Filosofia Política de Thomas Hobbes...

21. A associação de Hobbes com a primeira imagem foi difundida por Waltz. Curiosamente, a idéia hobbesiana aqui discutida, de que o medo resulta da incerteza quanto às intenções alheias, e não da natureza humana, vai ao encontro do que um dos seguidores de Waltz, Mearsheimer (1995:10), tratou como o terceiro pressuposto do realismo: "os Estados nunca podem estar certos quanto às intenções de outros Estados". O mesmo afirma outro autor neo-realista, Grieco (1993:128).

22. "Dado que a matéria dessa nutrição consiste em animais, vegetais e minerais, Deus colocou-os generosamente ao nosso alcance, à superfície da terra ou perto dela, de modo tal que não é preciso mais do que trabalho e esforço para colhê-los. A tal ponto a abundância depende simplesmente (a seguir ao favor de Deus) do trabalho e do esforço dos homens" (Hobbes, 1996:170).

23. É importante ressaltar que, embora em Do Cidadão Hobbes afirme que a razão possa, por si só, convencer os indivíduos da irracionalidade de seus interesses tal como definidos a partir de doutrinas perversas - sendo, por conseguinte, "dever daqueles que têm a autoridade suprema extirpá-las das mentes, não dando ordens, mas pelo ensino; não pelo terror dos castigos, mas pela perspicuidade das razões" (Hobbes, 2002:203) -, no Leviatã ele reconhece a necessidade de suplementar as descobertas da razão com as artes da persuasão (Skinner, 1999:572-573).

24. Este é um dos pontos mais enfatizados por Freyberg-Inan (2004:87): “[...] enquanto Maquiavel e Hobbes estavam fundamentalmente interessados em defender a racionalidade baseada no auto-interesse como uma solução promissora para o problema das paixões na política e na vida cívica, o realismo contemporâneo fia-se cada vez mais na racionalidade como pressuposto empírico".

25. Esse é também o argumento de Hayward Alker (1996:374, ênfases no original): "Reconhecendo que o apoio motivacional é necessário para que os sujeitos dentro de um Estado sigam os ditames de sua razão natural, e que as paixões também podem distorcer sua capacidade de raciocínio, Hobbes deseja de alguma forma criar uma ordem política que molde as emoções das pessoas de forma que elas desejem ser pacificamente racionais, e será circunstancialmente apropriado que elas o sejam".

26. Spinoza (apud Bull, 1966:45) ressalta esse ponto ao qualificar a analogia das relações entre indivíduos e entre Estados: “[...] uma nação pode se proteger contra a subjugação alheia, enquanto um homem no estado de natureza não pode. Porque, por certo, um homem é dominado pelo sono todos os dias, é freqüentemente atingido por doenças corporais e mentais e é finalmente prostrado pelo avanço de sua idade; ademais, está sujeito a outros problemas contra os quais uma nação pode se guardar". 
Iara Costa Leite

27. Vários autores realizaram, posteriormente, comparações similares entre indivíduos e Estados, de forma a demonstrar que a relação entre estes não remete ao estado de natureza. Ver, por exemplo, Charles Beitz (1979), que adiciona às comparações aqui tratadas dois outros fatos: (1) ao contrário dos indivíduos (que são os únicos atores no estado de natureza), os Estados não são os únicos atores nas relações internacionais; (2) a moral não é totalmente ausente, já que se verificam, na esfera internacional, expectativas de aderência recíproca às regras de cooperação.

28. Embora também seja a obediência função do medo, Hobbes (2002:56) afirma que "[...] deve ser tido por injusto quem age corretamente só por medo ao castigo apenso à lei [...]”.

29. Tal ignorância, como vimos, pode ser eliminada, notadamente, pela autoridade da razão. Assim nos diz Hobbes (2001:92), em seu Behemoth: “[...] não tenho dúvidas de que a razão sólida, amparada pela autoridade de inúmeros eruditos, será mais decisiva do que qualquer vitória sobre os rebeldes para manter a paz conosco".

30. Além das paixões e da ignorância dos homens, outro fator incluído por Hobbes no que chama de "sementes da mortalidade natural da soberania" são as guerras estrangeiras (Hobbes, 1996:153). Porém, como veremos mais adiante, mesmo os infortúnios internacionais podem ser evitados pelo cumprimento efetivo, por parte dos soberanos e dos cidadãos, de algumas tarefas.

31. "[...] um monarca soberano, ou a maioria de uma assembléia soberana, pode ordenar a realização de muitas coisas seguindo os ditames de suas paixões e contrariamente a sua consciência [...]" (Hobbes, 1996:172).

32. A citação que dá embasamento a essa afirmação é a de que "[...] na maioria dos casos, se porventura o interesse público se chocar com o interesse particular, ele [o soberano] preferirá o particular: pois é comum as Paixões dos homens serem mais potentes do que sua Razão” (Hobbes apud Skinner, 1999:464).

33. A definição da segurança dos súditos abrange, como veremos, “[...] não a mera preservação de suas vidas, mas geralmente seu benefício e bem" (Hobbes, 1999:172).

34. Hobbes (1996:222) afirma que o soberano que, na esperança de recuperar facilmente o poder absoluto, permite seu enfraquecimento, demonstra que não raciocina corretamente, e isso pelos motivos já assinalados. Afirma, ainda, que outra coisa que contribui para o enfraquecimento da comunidade civil (por razões que veremos adiante) é o “[...] apetite insaciável, ou bulimia, de alargar os domínios [...]"(idem:230). 


\section{Argumentos para uma Dissociação da}

Filosofia Política de Thomas Hobbes...

35. Isso não significa que Hobbes dispense completamente o papel desempenhado pelo resultado das interações entre Estados em um ambiente anárquico na determinação da conduta dos soberanos, o que fica claro quando diz, por exemplo, que os gastos da comunidade civil não são determinados por seu apetite próprio, mas pelos acidentes externos e apetites dos seus vizinhos (Hobbes, 1996:173).

36. Isso nos parece similar à conclusão de Maquiavel (2002:122), em O Príncipe, de que "[...] a melhor fortaleza é a construída sobre a estima dos súditos, pois as fortificações não salvarão um príncipe odiado pelo povo".

\section{Referências Bibliográficas}

ALKER, H. R. (1996), Rediscoveries and Reformulations: Humanistic Methodologies for International Studies. Cambridge, Cambridge University Press.

ALMEIDA, J. M. (1999), “Challenging Realism by Returning to History: The British Committee's Contribution to IR Forty Years On”, disponível em $<$ http://www.leeds.ac.uk/polis/englishschool $>$.

ARMSTRONG, D. M. (1978), Universals and Scientific Realism. Cambridge, Cambridge University Press.

ASHLEY, R. Q. (1986), “The Poverty of Neorealism”, in R. O. Keohane (ed.), Neorealism and its Critics. New York, Columbia University Press, pp. 255-300.

. (1988), "Untying the Sovereign State: A Double Reading of the Anarchy Problematique”. Millennium, vol. 17, n² 2, pp. 227-262.

BEITZ, Charles R. (1979), Political Theory and International Relations. Princeton, New Jersey, Princeton University Press.

BOBBIO, N. (1991), Thomas Hobbes. Rio de Janeiro, Editora Campus. 
Iara Costa Leite

BOROT, L. (1996), “History in Hobbes's Thought”, in T. Sorell (ed.), The Cambridge Companion to Hobbes. Cambridge, Cambridge University Press, pp. 305-328.

BULL, H. (1966), "Society and Anarchy in International Relations”, in H. Butterfield e M. Wight (eds.), Diplomatic Investigations. London, George Allen \& Unwin LTD, pp. 35-50.

(2000), "Hobbes and the International Anarchy", in K. Alderson e A. Hurrell (eds.), Hedley Bull on International Society. London, Macmillan Press, pp. 188-205.

BUZAN, B. e LITTLE, R. (2000), International Systems in World History. Remaking the Study of International Relations. Oxford, Oxford University Press.

BUZAN, B., JONES, C. e LITTLE, R. (1993), The Logic of Anarchy. New York, Columbia University Press.

CAMPBELL, D. (1992), Writing Security: United States Foreign Policy and the Politics of Identity. Minneapolis, University of Minnesota Press.

FLATHMAN, R. E. (1993), Thomas Hobbes: Skepticism, Individuality and Chastened Politics. London, SAGE.

FREYBERG-INAN, A. (2004), What Moves Man: The Realist Theory of International Relations and its Judgment of Human Nature. Albany, New York, State University of New York Press.

GASKIN, J. (1999), Introduction to Human Nature and De Corpore Politico, by Thomas Hobbes. New York, Oxford University Press, pp. xi-xlii.

GERT, B. (1996), “Hobbes's Psychology, in T. Sorell (ed.), The Cambridge Companion to Hobbes. Cambridge, Cambridge University Press, pp. 157-174.

GILPIN, R. G. (1984), “The Richness of the Tradition of Political Realism”. International Organization, vol. 38, n ${ }^{\circ}$, pp. 287-304.

GRIECO, J. M. (1993), “Anarchy and the Limits of Cooperation: A Realist Critique of the Newest Liberal Institutionalism", in D. A. Baldwin (ed.), Neorealism and Neoliberalism: The Contemporary Debate. New York, Columbia University Press, pp. 116-142.

HANSON, Donald W. (1984), “Thomas Hobbes's 'Highway to Peace””. International Organization, vol. 38, n 2, pp. 329-354. 


\section{Argumentos para uma Dissociação da}

Filosofia Política de Thomas Hobbes...

HERZ, J. (2001), "Idealist Internationalism and the Security Dilemma", in A. Linklater (ed.), International Relations. Florence, KY, USA, Routledge, pp. 260-278, vol. I

HOBBES, Thomas. (1996), Leviathan. Cambridge, Cambridge University Press.

(1997), A Dialogue between a Philosopher and a Student of the Common Laws of England. Chicago, The University of Chicago Press.

(1999), Human Nature and De Corpore Politico. New York, Oxford University Press.

(2001), Behemoth ou o Longo Parlamento. Belo Horizonte, Editora UFMG.

(2002), Do Cidadão ( $3^{\mathrm{a}}$ ed.). São Paulo, Martins Fontes.

HUTCHINGS, K. (1999), International Political Theory: Rethinking Ethics in a Global Era. London, SAGE Publications.

KAVKA, G. K. (1983), “Hobbes's War of All against All”. Ethics, vol. 93, pp. 291-310.

KEOHANE, R. O. (1993), “Theory of World Politics: Structural Realism and Beyond", in P. R. Viotti e M. V. Kauppi, International Relations Theory: Realism, Pluralism, Globalism. Boston, Allyn and Bacon, pp. 186-223.

(1995), “Hobbes's Dilemma and Institutional Change in World Politics: Sovereignty in International Society", in H.-H. Holm e G. Sorensen, Whose World Order? Uneven Globalization and the End of the Cold War. Boulder, Westview Press.

KRATOCHWIL, F.V. (2001), "Constructivism as an Approach to Interdisciplinary Study”, in K. M. Fierke e K. E. Jorgensen (eds.), Constructing International Relations: The Next Generation. London, M. E. Sharpe, pp. 13-35.

MEARSHEIMER, J. J. (1995), “The False Promise of International Institutions". International Security, vol. 19, n 3, pp. 5-49.

NAVARI, C. (1996), "Hobbes, the State of Nature and the Laws of Nature", in I. Clark e I. B. Neumann (eds.), Classical Theories of International Relations. New York, St. Martin's Press, pp. 20-41. 
Iara Costa Leite

ODYSSEOS, L. (2002), "Dangerous Ontologies: The Ethos of Survival and Ethical Theorizing in International Relations". Review of International Studies, vol. 28, pp. 403-418.

ONUF, N. G. e ONUF, P. (no prelo), One Nation or Two? Modern History and the Crisis of the Federal Union.

SCHMIDT, B. C. (1998), The Political Discourse of Anarchy: A Disciplinary History of International Relations. Albany, NY, State University of New York Press.

SKINNER, Q. (1999), Razão e Retórica na Filosofia de Hobbes. São Paulo, Fundação Editora da UNESP.

SORELL, T. (1996), "Hobbes's Scheme of the Sciences”, in The Cambridge Companion to Hobbes. Cambridge, Cambridge University Press, pp. 45-61.

TUCK, R. (1996), “Introduction” in Leviathan. Cambridge, Cambridge University Press, pp. ix-xlv.

_. (2001), Hobbes. São Paulo, Edições Loyola.

WALKER, R. B. (1993), Inside/Outside: International Relations as Political Theory. Cambridge, Cambridge University Press.

WALTZ, K. (1959), Man, the State, and War. New York, Columbia University Press.

WENDT, A. (1999), Social Theory of International Politics. Cambridge, Cambridge University Press.

(2000), "Anarchy is what States Make of it", in A. Linklater (ed.), International Relations. Florence, KY, USA, Routledge, pp. 615-651, vol. II.

WIGHT, M. (1966), “Why Is There no International Theory?, in H. Butterfield e M. Wight (eds.), Diplomatic Investigations. London, George Allen \& Unwin LTD, pp. 17-34.

(1991), International Theory. The Three Traditions. Leicester/London, Leicester University Press.

WILLIAMS, M. C. (1996), "Hobbes and International Relations: A Reconsideration". International Organization, vol. 50, nº 2, pp. 213-236. 


\section{Argumentos para uma Dissociação da}

Filosofia Política de Thomas Hobbes...

ZARKA, Y. C. (1996), "First Philosophy and the Foundations of Knowledge", in T. Sorell (ed.), The Cambridge Companion to Hobbes. Cambridge, Cambridge University Press, pp. 62-85.

ZEHFUSS, M. (2001), “Constructivisms in International Relations: Wendt, Onuf and Kratochwil”, in K. M. Fierke e K. E. Jorgensen (eds.), Constructing International Relations: The Next Generation. London, M. E. Sharpe, pp. 55-75.

\section{Resumo}

\section{Argumentos para uma Dissociação da Filosofia Política de Thomas Hobbes da Tradição Realista}

O propósito deste artigo é desconsagrar o caráter heróico que a obra de Hobbes assumiu para os estudantes de relações internacionais ao ter sido enquadrada - assim como as de Tucídides, Maquiavel, Rousseau, Hegel etc. - no épico realista. Veremos que a subsunção do filósofo à "tradição realista" é raramente questionada, mesmo pelos críticos das concepções veiculadas por essa tradição. Assim, o nome de Hobbes permanece, em grande medida, associado à analogia entre anarquia internacional e estado de natureza. Em primeiro lugar, o artigo resgata o caráter hipotético do modelo de estado de natureza, dando ênfase especial ao reconhecimento de Hobbes à limitação de seu reducionismo motivacional para a descrição da realidade. Em segundo, partindo do pressuposto de que a dicotomia interno-externo era inexistente na época de Hobbes, explora, a partir de sua obra, o argumento de que a paz internacional estaria diretamente relacionada à resolução do problema da ordem nas sociedades domésticas.

Palavras-chave: Anarquia Internacional - Estado de Guerra - Teoria de Relações Internacionais - Thomas Hobbes 
Abstract

\section{Arguments for a Dissociation of Thomas Hobbes' Political Philosophy from the Realist Tradition}

The purpose of this article is to deconsecrate the heroic status that international relations students have attached to Hobbes's texts - an attachment that results from their inclusion, together with texts by Thucydides, Machiavelli, Rousseau and Hegel, in the realist epic. We will see that the subsuming of the philosopher under the "realist tradition" is rarely questioned, even by the critics of the conceptions endorsed by it. Therefore, the name of Hobbes remains, in a large extent, associated to the analogy between international anarchy and the state of nature. In the first place, we'll bring to light the hypothetical status of the state of nature model, emphasizing the fact that Hobbes himself recognized the limitation of its motivational reductionism to the description of reality. Secondly, having taken as a premise the fact that the dichotomy inside/outside did not exist in Hobbes's time, we'll explore the argument that international peace would be directly associated to the resolution of the problem of order in domestic societies.

Key words: International Anarchy - State of War - Theory of International Relations - Thomas Hobbes 